\title{
Demographic Variables as Factors Influencing Accessibility and Utilisation of Library Software by Undergraduates in two Private Universities in Nigeria
}

\author{
Akano Tolulope ${ }^{1}$ \\ 'Librarian, Adeleke University, Ede, Osun State. Nigeria
}

\begin{abstract}
Libraries before the 21 st century carried out daily routine library task such as cataloguing and classification, acquisition, reference services etc using manual procedures only but the advent of Information Technology as transformed these routine task that libraries can now automate their activities by deploying the use of library software in carrying its routine task. Library automation no doubt offers many opportunities to improve library services to library patrons. Despite the numerous benefits derived from library software, its $j$ use by users during information search in the library it still at a formative stage because most users do not use the library software. The study was based on appraising demographic variables as factors influencing accessibility and utilisation of library software by undergraduates in two -selected private universities in Nigeria with the- objectives of investigating the purpose of using the software, determining the benefits and challenges of using a library software in managing its collection: Descriptive survey was adopted for the study and the study population comprised of a total population of 4.860 undergraduates: 2,210 in Redeemers University and 2,660 in Bowen University. Simple random sampling was used with a sampling fraction of five percent to give a sample size of 244. The questionnaire was the main instrument complemented with interview guide for the systems analyst and observation checklist. The data was analysed using frequency distribution with percentages and regression analysis. Undergraduates in Bowen that used the library software were male in 3001evel between ages 16-20years while those in Redeemers that used the library software were female students in 2001evel between 16-20 years. Both universities had functional and accessible library software and 67 and 70 respondents in Bowen and Redeemers University respectively stated that the software was user friendly and access to the software was free for all registered users of the library. Undergraduates in Bowen used the library software occasionally for assignments 36(36.4\%) and project 31(31.3\%) while those in Redeemers used it for assignments $49(44.1 \%)$ and term paper 36(32.4\%). In both universities undergraduates learnt to use the library software through training from library staff $(72.7 \%$ in Bowen and $47.7 \%$ in Redeemers). Also, the benefit derived from having a library software in the library included time saved and assistance in carrying out their research. Some identified major challenges included frequent downtime of software package and server and irregular power supply. There was also a joint effect of demographic variables on utilisation of library software by undergraduates $(\mathrm{r} 2=0.035, \mathrm{p}<0.05)$ and there was a significant relationship between gender and utilisation of library software $(\mathrm{r} 2=0.140 . \mathrm{p}<0.05)$. Deployment of library software for the routine task has helped to ensure proper management and retrieval of resources; however its use is still minimal that undergraduates should be encouraged to make maximum use of the software regularly when searching for library materials. For improved use of the software, librarians should make the undergraduates aware of the software and its benefits and also evaluate the software to ensure that it is still meeting the needs of the users.
\end{abstract}

Keywords: Accessibility: ability to obtain resources and information in all formats where it is located, from anywhere and at any time. Demographic variables: are the population statistics with regard to socioeconomic factors such as age, income, sex, occupation, education, family size; and the like, Influencing : effect on something.

It was considered necessary to define the major terms used in their study.

Library Software: is an integrated library system (ILS). also known as a library management system (LMS), is an enterprise resource planning system for a library, used to track items owned, orders made, bills paid, and patrons who have borrowed.

Private university: are non-public or independent universities who do not receive governmental funding and are usually administered by denominational or secular boards; others are universities operated for profit.

Undergraduate: is a student who is undertaking a first- level degree programme of study, normally a bachelor's degree or equivalent.

University library: is a library established, administered and funded by a university to meet the information, research and curriculum use of the student, faculty and staff Utilization: to make use of something for ones benefit. 
Citation | Akano Tolulope (2017). Demographic Variables as Factors Influencing Accessibility and Utilisation of Library Software by Undergraduates in two Private Universities in Nigeria. of Education and e-Learning Research, 4(3): 92-99.

History:

Received: 25 October 2017

Revised: 28 September 201

Accepted: 5 October 2017

Published: 13 October 2017

Licensed: This work is licensed under a Creative Commons

Attribution 3.0 License $(\mathrm{cc})$ EY

Publisher: Asian Online Journal Publishing Group
Funding: This study received no specific financial support.

Competing Interests: The author declares that there are no conflicts of interests regarding the publication of this paper.

Transparenc The authors confin that the manuscript is an honest, was reported; that no vital features of the study have been omitted; and that any discrepancies from the study as planned have been explained.

Ethical: This study follows all ethical practices during writing.

\section{Contents}

1. Background of the Study

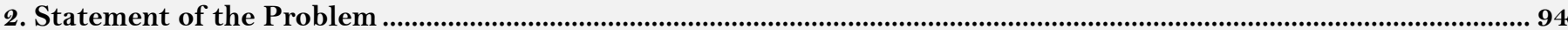

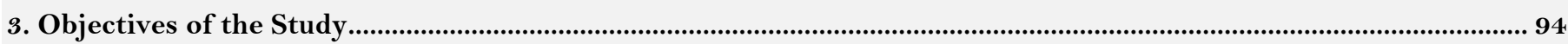

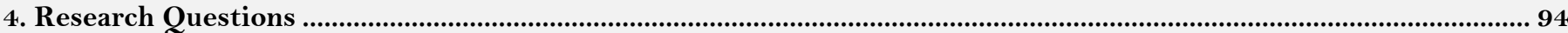

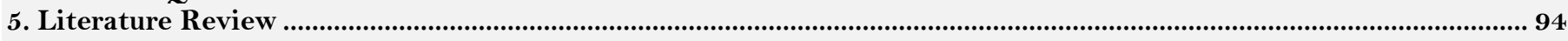

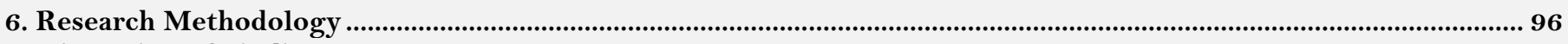

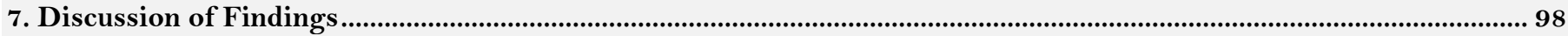

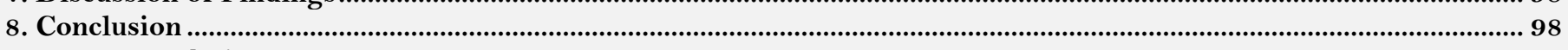

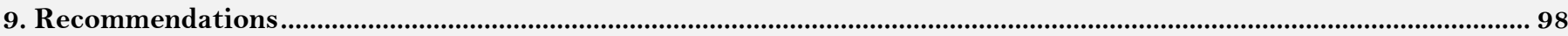

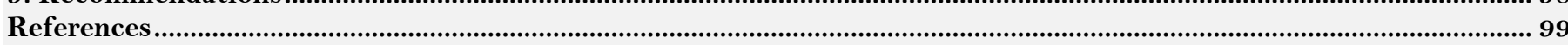

\section{Background of the Study}

University is a place where skilled manpower of various capacities is being trained. It is also a boulevard to develop human capital needed to sustain the economy. Establishment of universities in Nigeria has been limited by the amount of money-made available by either the federal or state government depending on the owner. But recently, the federal government was aware that there is the need to involve private individuals and corporations in the ownership, funding and management of universities, more so, that it is becoming more difficult for the government to cope with the cost of running the university education and cost of expanding the existing universities as a result of dwindling world economy.

Private universities are a recent development in Nigeria as compared to the federal and state government owned universities. It has evolved during two historic phases: the first during the second republic under President Shehu Shagari administration 1979 - 1983 (all facilities). The second phase was during the fourth republic under President Olusegun Obasanjo (1999 -2007). During this phase necessary machines were put in place to visit and scrutinize applications from individuals, religious and corporate organizations of who are applying for private universities operating license. To Reified arid Belfied and Lerin (2003) private universities are non-public or independent universities who do not receive governmental funding and are usually administered by denominational or secular boards; others are universities operated for profit. Olaniyan (2001) also refer to private universities as those universities that are solely owned, financed and managed by private individuals with intention to recover cost in short time and make profit.

The university library therefore is the academic heart of the university system and its basic purpose is to provide university staff, students, and other researchers with materials assistance and an enabling environment that would facilitate teaching, learning and research. It is important for library services to focus more on the use of resources provided for their patrons.

According to Whitmire (2002) academic library resources are considered a good measure of an institution's excellence and quality. Popoola (2008) affirmed that the information resources and services available in institutional information systems must be capable' of supporting research activities among the students and faculty members.

lyoro (2004) in his study identified accessibility as one of the pre-requisites of information use. Ugah (2007) opined that the more accessible information sources are, the more likely they are to be used and readers tend to use information sources that require the least effort to access.

In this vein, library software can simply be defined as a library management system, also known as an automated library system that has been developed to handle basic housekeeping functions of a library. The Computerization of library activities therefore is the application of computers to carry out library operations that were manually performed. Library software has become the most powerful tool for changing the scenario of libraries, from traditional to automated, from automated to electronic, from electronic to digital, and from digital to virtual (Singh, 2003).A number of software packages have been developed for use in the management and dissemination of data in libraries. Some have been developed by commercial agencies (open source software); others have been developed indigenously by institutions for in house use (closed source software); and there is yet another class where customized applications have been generated on the basis of existing software, Singh (2003).

On the other hand, demographic variables therefore are the characteristics of a human population. It can also be seen as statistical socio-economic characteristics or variables of a population, such as age, gender, educational level, income level, marital status, occupation, religion, both rate, death rate, disabilities, mobility, average size of a family, and average age at marriage.

Gender refers to the socially constructed roles, behaviours, activities, and attributes that a given society considers appropriate for men and women, educational qualifications are the degrees, diplomas, certificates, professional titles and so forth that an individual has acquired whether by full-time study, part-time study or private study, whether conferred in the home country or abroad, and whether conferred by educational authorities, special examining bodies or professional bodies while age is the length of time that one has existed; duration of life (World Health Organization, 2011). 
A study done by Yuandong et al. (2005) concluded that age and gender will influence the attitude of rural community towards ICT usage. Gender has always been an important factor to constitute positive attitude and gender differences proved to have a significant impact on some studies Sayan et al. (2004); Olatokun (2007) has come to a specific result when he claimed that females do have a positive attitude towards ICT usage.

\section{Statement of the Problem}

At the commencement of the automation of libraries in the early seventies, Nigerian academic libraries were beset with a myriad of problems such as huge cost, lack of technical skills by library personnel, epileptic power supply and other such problems that discouraged them from fully embracing automation. Over the years however, with the realization of the immense benefits and the abundant opportunities and possibilities offered by automation, Nigerian academic libraries had no options than to key into the automation race. Despite the numerous benefits derived from library software, its use by users during information searches in the library it still at a formative stage because most users do not use the library software. This study hopes to fill the gap of making users aware of the usefulness of library software when searching a library's collection.

\section{Objectives of the Study}

The major objective of the study is to find out the demographic variables influencing the accessibility and use of software and their application in private university libraries in Nigeria. The specific objectives are to:

1. identify the demographic variables of undergraduates in selected private universities

2. find out the accessibility of the software package to undergraduates

3. find out the frequency of software use by the undergraduates

4. investigate the purpose of using software package by the undergraduates

5. examine how undergraduates learnt how to use the software package

\section{Research Questions}

To achieve the above objectives the following research questions were framed

1. What are the demographic variables of undergraduates in selected private universities?

2. How accessible is the software package to the undergraduates?

3. How frequently do the undergraduates make use of the software?

4. What do the undergraduates use the software package for?

5. How did undergraduates learnt to use the software package?

\section{Literature Review}

\subsection{Accessibility and Utilization of Library Software by Undergraduates}

There is a dearth in the literature about library software accessibility and utilization by library users however much has been done on library resources utilization. Over the past decade, most libraries in Nigeria have been experiencing much difficulty in providing materials to the users on account of the alarming rate of inflation of the prices of books and journals as well as depreciation value of the Nigerian economy (Ehikhamenor, 1993). Ugah (2007) quoted Osundina (1974) who studied the relationship between accessibility and library use by undergraduates in Nigeria and noted that the problem of Nigerian students is not the question of wanting to use the college library, but whether or not the university library can provide for their needs, and whether there is access to what is provided. This assertion was agreed to in later studies by lyoro (2004) and Popoola (2008). In separate studies, Seth and Parida (2006); Ugah (2007); Nnadozie and Nnadozie (2008) cautioned that availability of information resources and services does not automatically translate to information accessibility and use.

A study was conducted by Harinarayana and Raghavan (2008) who examined the comparative retrieval effectiveness of two packages, viz., CDS/ISIS and LibSys. A set of eightwell-defined parameters were employed to compare the two packages. The result shows that neither of the two packages provides support for all the features that may be expected of ideal retrieval software. There appears to be some significant difference between CDS/ISIS and LibSys in terms of their ability to provide desirable features. There is a difference of $9.34 \%$ in the levels of performance of the two packages.

Another study carried out by Bensode and Periera (2008) on the status of automation in the colleges of Goa similar to that of college libraries throughout India, Libraries, librarians, and college administrators must start automation to provide effective and efficient services to users. The authors suggest that library professionals must upgrade their skills to meet the growing expectations of users from libraries.

Ugah (2007) in a study the problems of transmission, storage, and display of information combined with the problem of getting-information to users quickly. Although online searching and electronic bibliographic databases are now available in almost every field which confirms that as information expands, the ability of the user to process it remains fixed (Seth and Parida, 2006).

\subsection{Computerization of University Libraries in Nigeria}

University library computerization in Nigeria has been in the pipeline since the 1970s, although concerted efforts began in the late 1990s. In 1970, lya Abubakar delivered a lecture in a meeting of the Nigerian Library Association (NLA), the national association that is equivalent to the American Library Association (ALA). The theme of the lecture was the library and the computer. Nok (2006) quoting Abolaji (2000) reported that significant and widespread efforts at computerizing library services started in the 1990s.

Computerization of library activities therefore is the application of computers to carry out library operations that were manually performed. Computerization of university libraries activities becomes inevitable if the libraries were to fulfill their role in the realization of universities' mission or goals, summarized as preservation, transmission and advancement of knowledge. This is so because information explosion has brought with it huge 
problems of management and control of not only the published sources of information but also less formally produced documents (Ifidon, 1999). Interestingly, a number of Nigerian libraries had attempted to automate their operations at one time or the other.

The concept of library automation has been widely embraced by university libraries in Nigeria. University of Lagos and Covenant University are reported to have achieved full automation of their libraries, while University of Agriculture, Abeokuta and Lagos State University attained partial automation (Okewale and Adetimirin, 2011).

In a study on adoption of software packages in university librariesin Nigeria, Edem (2016) in her work submitted that though only $20 \%$ of university libraries in Nigeria are not automated at all, it is thought provoking that only $5 \%$ of university libraries in Nigeria are fully automated. This leaves those with partial automation at $75 \%$. This implies that $95 \%$ of libraries in Nigerian universities are either not automated or partially automated. Going by the percentage of libraries in Nigerian universities with full automation, she concluded that the level of adoption of software packages in university libraries in Nigeria, cutting across federal, state and private universities, is very low.

\subsection{Demographic Variables Affecting Access and Use of Library Software in Nigeria}

Demographic variables often yield important clues as to what factors contribute to undergraduates' use of library software. Demographic variables such as age, gender etc affect the use of library software. Whitmire (2001a) found that there was a correlation between background characteristics such as gender, race, and initial critical thinking scores and library use during the freshmen and sophomore years, although these played less of an important role in the junior year. An interesting predictor of college library use was the degree to which these students used the library while in high school.

Age is one variable that correlates with comfort with computers and use of library software. Whitmire (2001a) found out that younger generations have been brought up with computers; many do not even remember a time when computers were not around. Older and returning students may not have had as much exposure to computers, resulting in increased computer anxiety. For example, Laguna and Babcock (1997) found out that, "...there were significant age differences on the computer task, as measured by older adults making fewer correct decisions and taking longer to make their decisions than younger adults." Studies have also found out that the more computer experience people have, the less anxious they are about using computers. Dyck and Smither (1994) found this true for younger and older subjects (recruited from senior citizens courses and continuing education courses). Therefore, given similar computer experience, age does riot seem to make a difference in people's comfort levels with computers. Medical doctors, who we assume have similar educational backgrounds, showed no difference in usage of library software in terms of-sex or age (Laerum et al., 2001).

\subsection{Gender}

Gender is another relevant factor in examining use of library software. In a study of high school students, it was found that their attitudes towards computers and their computer use tended to vary by gender. This difference, however, tended to diminish with computer experience (Sacks et al., 1994). Other studies have found similar results: Dyck and Smither (1994) for example, found that when the effects of computer experience were controlled, there were no gender effects." In a study of 60 college students, Koohang (1986) found that neither age nor gender was strongly correlated to computer anxiety, computer confidence or liking, but that computer experience was.

While the gender gap relating to computer use seems to be shrinking, several studies have found that there is a gender gap when considering use of the Internet and library software, and that gender is a major predictor of internet and library software use and access; males seem to enjoy browsing on the Internet for enjoyment while females tend to only use it for work-related purposes (Ford and Miller, 1996). In a study of highly successful students. Ford et al. (2001) found that females tended to experience more difficulty finding information on-line, to feel less competent and comfortable using the Internet, to use the Internet less frequently than males, and to make use of a less varied set of Internet applications. Majid and Abazova (1999) found a similar result in studying faculty members: while males tended to have better computing skills than females, age and year of obtaining highest educational qualifications were also important factors in establishing computer skills.

\subsection{Level of Education}

A study of student's use of library software found that it was "influenced by such factors as computing skills of academics, their age and gender. Majid and Abazova (1999) found that there is an especially significant relationship between computing skills and use of library software in the library, including the Online Public Access Catalogue (OPAC). Students with higher computing skills were not only more likely to use and be familiar with the library software, including the OPAC, but also tended to use the Internet more frequently (Majid and Abazova, 1999).

\subsection{Frequency of Computer Use}

Computer anxiety is another contributing reason that discourages users from taking advantage of library resources and services (Brosnan, 1998). Much of today's information technology makes use of computers, it is important to investigate the relationship between computer use by students and their use of library software in the library. A study of faculty at Western Michigan University showed that frequent users of the library tended to make greater use of computer applications and the library's databases than infrequent users, and also reported higher expertise in using these applications (Meer et al., 1997). Moreover, the level of computing and Internet experience: with which students enter higher education might influence whether or not they will use the library's software (McGuigan, 2001). Students' library use is another variable influencing the use of the library's software. It is ' reasonable to assume that the more an undergraduate uses the library, the more familiar the student will be with its resources, including its library software. However, if students use the library primarily as a quiet and convenient place to study, they may not be aware of its resources at all, as compared to the student who never 
puts a foot in the library. Several studies have shown that undergraduates use the library mostly as a place to study and make photocopies, but do not make great use of some of the available library services, such as interlibrary loan and the reference desk (Whitmire, 2001b).

A longitudinal study of undergraduates by Whitmire (2001a;2001b) shows that library use by undergraduates changes according to their status. In particular, she found that library use increased from freshmen to junior years, especially in the use of computers for research, although this might also be because juniors have more assignments where they need to do research.

\section{Research Methodology}

\subsection{Population of the Study}

The population size of the study was composed of two private universities library in Nigeria with the total population of four thousand eight hundred and seventy $(4,870)$ respondents. Redeemers' university library has two thousand two hundred and ten $(2,210)$ clientele while BOWEN university library has two thousand six hundred and sixty $(2,660)$ clientele (Table 1.1).

\subsection{Sample Technique and Sample Size}

Simple random sampling was adopted in selecting the sample. A sample is called simple random sample if each unit of the population has an equal chance of being selected for the sample. The selected subject from the population under investigation are two private universities library with the total population of four thousand eight hundred and seventy $(4,870)$ using $5 \%$ as sampling fraction for Redeemers' university library and BOWEN university library. The sample size is 244 (Table $1: 1$ ).

Table-1.1. Sample-population and sample size

\begin{tabular}{l|l|l|l}
\hline Name of Library & Name of Software & Population & Sample Size \\
\hline Redeemers' university library & LIBRARY PORTAL & 2,210 & 111 \\
\hline BOWEN university library & KOHA & 2,660 & 133 \\
\hline Total & & 4,870 & 244 \\
\hline Source: From data collected &
\end{tabular}

\subsection{Methods of Data Analysis}

The statistical techniques and tools employed in analyzing the data collected for the study was frequency distribution and analysis of variance (ANOVA) which is used to normally test the effects of qualitative independent variables on a quantitative dependent variable and the result will be presented in tables and percentages.

\section{Research Question 1: What are the demographic variables of undergraduates in the selected private universities?}

Table 1.2 showed that majority of the respondents $37(37.4 \%)$ in Bowen University were in 3001 evel and those in Redeemers university were in 200 level 48(43.2\%). Most of the respondents in Bowen were male $(50.5 \%)$ and those in Redeemers were female (54.1\%). Also, the age of the respondents was between $16-$ 20 years in both universities. About 99 respondents in Bowen and 109 respondents in Redeemers were single and Christians as well except $1(1.0 \%)$ that was a Muslim. Most of the respondents in both universities had $\mathrm{SSCE}$ as the highest educational qualification.

Table-1.2. Demographic Variables of Respondents

\begin{tabular}{|c|c|c|c|c|c|c|c|}
\hline \multirow[t]{3}{*}{ Variables } & & \multicolumn{6}{|c|}{ University } \\
\hline & & \multicolumn{2}{|c|}{ Bowen } & \multicolumn{2}{|c|}{ Redeemer's } & \multicolumn{2}{|c|}{ Total } \\
\hline & & $\mathbf{N}$ & $\%$ & $\mathbf{N}$ & $\%$ & $\mathbf{N}$ & $\%$ \\
\hline \multirow[t]{5}{*}{ Level } & 100 & 3 & 3.0 & 3 & 2.7 & 6 & 2.9 \\
\hline & 200 & 24 & 24.2 & 48 & 43.2 & 72 & 34.3 \\
\hline & 300 & 37 & 37.4 & 40 & 36.0 & 77 & 36.7 \\
\hline & 400 & 27 & 27.3 & 18 & 16.2 & 45 & 21.4 \\
\hline & 500 & -8 & 8.1 & 2 & 1.8 & 10 & 4.8 \\
\hline \multirow[t]{2}{*}{ Gender } & Male & 50 & 50.5 & 51 & 45.9 & 101 & 48.1 \\
\hline & Female & 49 & 49.5 & 60 & 54.1 & 109 & 51.9 \\
\hline \multirow[t]{5}{*}{ Age (Years) } & $<16$ & - & - & 1 & 0.9 & 1 & 0.5 \\
\hline & $16-20$ & 64 & 64.6 & 86 & 77.5 & 150 & 71.4 \\
\hline & $21-24$ & 33 & 33.3 & 22 & 19.8 & 55 & 26.2 \\
\hline & $25-29$ & 2 & 2.0 & 1 & 0.9 & 3 & 1.4 \\
\hline & $>29$ & - & - & 1 & 0.9 & 1 & 0.5 \\
\hline \multirow[t]{2}{*}{ Marital status } & Single & 99 & 100 & 109 & 98.2 & 208 & 99.0 \\
\hline & Married & - & - & 2 & 1.8 & 2 & 1.0 \\
\hline \multirow[t]{2}{*}{ Religion } & Christianity & 98 & 99.0 & 110 & 99.1 & 208 & 99 \\
\hline & Islam & 1 & 1.0 & 1 & 0.9 & 2 & 1.0 \\
\hline \multirow{3}{*}{$\begin{array}{l}\text { Highest } \\
\text { educational } \\
\text { Qualification }\end{array}$} & SSCE & 90 & 90.9 & 90 & 81.1 & 180 & 85.7 \\
\hline & NECO & 6 & 6.1 & 6 & 5.4 & 12 & 5.7 \\
\hline & Others & 3 & 3.0 & 15 & 13.5 & 18 & 8.6 \\
\hline
\end{tabular}

1.3: Research Question 2: How accessible is the software package to the undergraduates?

Table 1.3 revealed that majority of the respondents in Bowen 93(93.9\%) and Redeemers 105(94.6) universities reported that the library software was accessible while only six respondents in both 
universities stated that it was not accessible. Also, respondents in Bowen 91(91.9\%) and respondents in Redeemers 98(88,3\%) affirmed that the library software was user friendly while only eight in Bowen and thirteen in Redeemers reported that it was not user friendly. During my visit to the universities the library software was working.

From the interview conducted for the system analyst in both universities, the software was integrated and Bowen library had about twenty-one computers while Redeemers Library had about sixty computers to provide access to the library's collection. Also, access was free to all registered library users in both universities.

Table-1.3 Accessibility of Software Package by undergraduates

\begin{tabular}{|c|c|c|c|c|}
\hline Software Accessibility & $\begin{array}{l}\text { Bowen } \\
\mathbf{N} \\
\end{array}$ & $\begin{array}{l}\text { Redeemers } \\
\mathbf{N} \%\end{array}$ & $\begin{array}{l}\text { Total } \\
\mathbf{N}\end{array}$ & $\%$ \\
\hline Not accessible & $\begin{array}{ll}6 & 6.1 \\
\end{array}$ & $\begin{array}{ll}6 & 5.4 \\
\end{array}$ & 12 & 5.7 \\
\hline Accessible & 51.5 & 57.7 & 115 & 54.8 \\
\hline Very accessible & 42,4 & 36.9 & 83 & 39.5 \\
\hline Total & 100 & 100 & 210 & 100 \\
\hline User friendliness & \begin{tabular}{|l} 
Bowen \\
$\mathrm{N}$
\end{tabular} & $\begin{array}{l}\text { Redeemers } \\
\mathrm{N}\end{array}$ & $\begin{array}{l}\text { Total } \\
\mathrm{N}\end{array}$ & $\%$ \\
\hline Not user friendly & 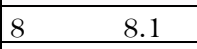 & $\begin{array}{ll}13 & 11.7 \\
\end{array}$ & 21 & 10.0 \\
\hline User friendly & 67.7 & 63.1 & 137 & 65.2 \\
\hline Very user friendly & 24,2 & 25.2 & 52 & 24.8 \\
\hline Total & 100 & 100 & 210 & 100 \\
\hline
\end{tabular}

Research Question 3: How frequently do the undergraduates make use of the software?

Table 1.4 revealed that majority of the respondents in Bowen $40(40.4 \%)$ and in Redeemers $47(42.3 \%)$ reported that they used the library software occasionally while in Bowen 3(3.0\%) and in Redeemers $10(9.0 \%)$ had never used the library software.

Table-1.4. Frequency of use of software

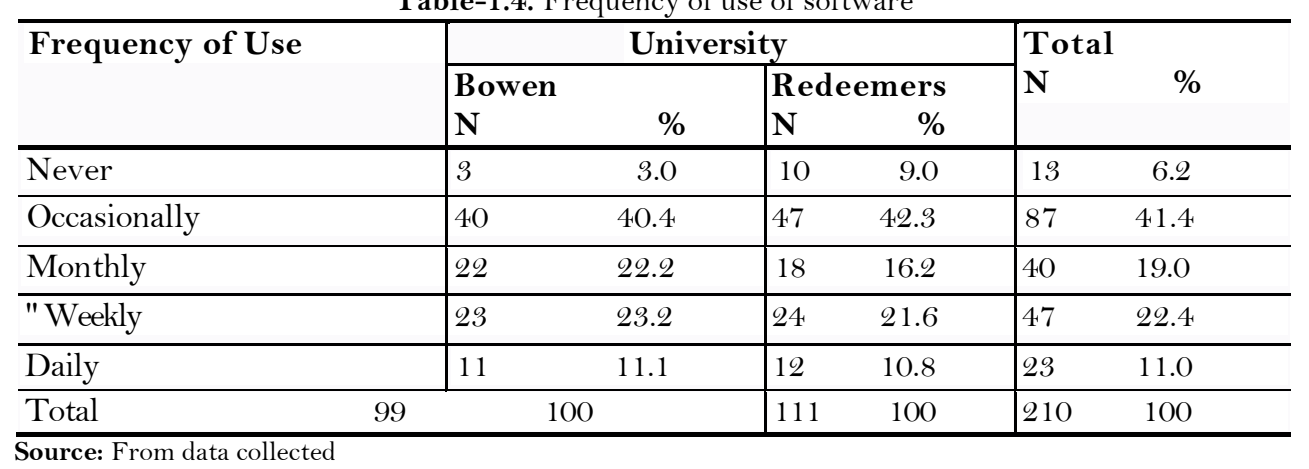

\section{Research Question 4: What do the undergraduates use the software package for?}

Table 1.5 revealed that majority of the respondents in Bowen 36(36.4\%) and Redeemers $49(44.1 \%)$ used the library software basically for assignment while $7(7.1 \%)$ respondents in Bowen used it for seminar and only $1(0.9 \%)$ respondent in Redeemers used it for other purpose.

Table-1.5. Purpose of Use of software

\begin{tabular}{|c|c|c|c|c|c|c|}
\hline \multirow[t]{3}{*}{ Purpose } & \multicolumn{4}{|c|}{ University } & \multirow{2}{*}{\multicolumn{2}{|c|}{ Total }} \\
\hline & \multicolumn{2}{|c|}{ Bowen } & \multicolumn{2}{|c|}{ Redeemer } & & \\
\hline & $\mathbf{N}$ & $\%$ & $\mathbf{N}$ & $\%$ & $\mathbf{N}$ & $\%$ \\
\hline Project & 31 & 31.3 & 18 & 16.2 & 49 & 23.3 \\
\hline Seminar & 7 & 7.1 & 7 & 6.3 & 14 & 6.7 \\
\hline Term paper & 25 & 25.3 & 36 & 32.4 & 61 & 29.0 \\
\hline Assignment & 36 & 36.4 & 49 & 44.1 & 85 & 40.5 \\
\hline Others & - & - & 1 & 0.9 & 1 & 0.5 \\
\hline Total & 99 & 100 & 111 & 100 & 210 & 100 \\
\hline
\end{tabular}

\section{Research Question 5: How did undergraduates learn to use the software Packages?}

Table 1.6 revealed that majority of the respondents $72(72.7 \%)$ in Bowen and in Redeemers university 53(47,7\%) learnt to use the library software through training from library staff and only 6(6.1\%) in Bowen and $10(9.0 \%)$ in Redeemers learnt to use the library software through trial and error.

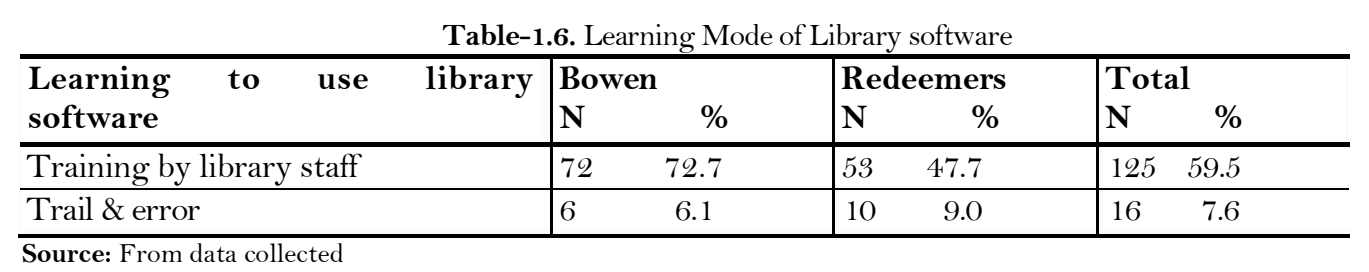

Table 1.6 revealed that majority of the respondents in Bowen 94(94.9\%) and Redeemers 105(94.6\%) universities agreed that library software saved their time and had helped in carrying out their research work and seminars while about $63(63.7 \%)$ in Bowen and Redeemers $94(84.7 \%)$ reported that library software enabled accessibility to the 
libraries resources. Also, only 5(5,0\%) in Bowen and 6(5.4\%) in Redeemers disagreed that library software saved time and helped in accessing information.

The system analyst reported that the benefit derived from having library software was ease of access to the library resources.

Table-1.7. Benefit of using library Software Package

\begin{tabular}{|c|c|c|c|c|c|c|c|c|}
\hline \multirow[t]{3}{*}{ Benefit } & \multicolumn{8}{|c|}{ University } \\
\hline & \multicolumn{4}{|c|}{ Bowen } & \multicolumn{4}{|c|}{ Redeemers } \\
\hline & \multicolumn{2}{|c|}{$\begin{array}{l}\text { Agree } \\
\mathbf{N}\end{array}$} & \multicolumn{2}{|c|}{$\begin{array}{l}\text { Disagree } \\
\mathbf{N} \%\end{array}$} & \multicolumn{2}{|c|}{ Agree } & \multicolumn{2}{|c|}{ Disagree } \\
\hline Saves time & 94 & 94.9 & 5 & 5.0 & 102 & 91.9 & 9 & 8.1 \\
\hline Gives up to date information & 87 & 87.9 & 12 & 12.2 & 104 & 93.7 & 7 & 6.3 \\
\hline User friendly & 90 & 90.9 & 9 & 9.1 & 101 & 91 & 10 & 9 \\
\hline Has helped me in my research work, seminar & 81 & 81.8 & 18 & 18.2 & 101 & -91 & 10 & 9 \\
\hline Has helped me in accessing information & 87 & 87.9 & 12 & 12.1 & 105 & 94.6 & 6 & 5.4 \\
\hline Costs of retrieving is reduced & 81 & 81.8 & 18 & 18.2 & 101 & 91 & 10 & 9.0 \\
\hline $\begin{array}{l}\text { Access is provided to more complete sets of } \\
\text { journals and other information resources }\end{array}$ & 80 & 80.8 & 19 & 19.2 & 96 & 86.5 & 15 & 13.5 \\
\hline $\begin{array}{l}\text { Resources will never be out on loan but will be } \\
\text { available at anytime, anyplace and anywhere }\end{array}$ & 63 & 63,7 & 36 & 36.4 & 94 & 84.7 & 17 & 15.3 \\
\hline
\end{tabular}

Source: From data collected

\section{Discussion of Findings}

The study found out that there were more male users of the library software in Bowen University than in Redeemers and there were also more female users of the library software in Redeemers than in Redeemers as well. The study also found out that library users in both universities were between ages 16-20 years.

Findings from the study also revealed that the library software was accessible and user friendly although it was only used occasionally in both Bowen and Redeemers universities. This justifies the primary goal of any library as identified by Nwalo (2003) who stated that the primary goal of any library is to acquire, organize, store, and make accessible to users within the quickest possible time all forms of information materials which they require. Also, the library software was used predominantly for project, assignment and term papers. Every user needs particular resources for his or her information needs. As Ranganathan (1931) stated in one of the laws of library science, "every reader his book".

Findings from the study further revealed that undergraduates basically learnt to use the library software through training from library staff in both universities and not through trial and error. This negates (Klatt, 2001) findings that students acquired their search skills through friends and courses taught in the university. Paramount among the benefits of having library software in both university libraries was that it saved time, gave up to date information, user friendliness, assistance in accessing and carrying out research and seminar works.

The major challenges that confronted the use of the library software were inadequate number of computers, lack of skill to access the software, power supply and frequent downtime of server amidst other challenges. This findings corroborates Zaid (2004) and Fatoki (2002) findings that identified current downturn in the Nigerian economy, shortage of manpower, problem with' the generation and distribution of power by Power Holding Company of Nigeria (PHCN).

The study was able to find out that there was a joint effect of the demographic variables on utilization of library software as well as relative contribution of gender on utilization of library software. Also, there was no significant relationship in the joint effect of demographic variables on accessibility of library software.

\section{Conclusion}

Academic libraries have a very important role to play in education and each educational institution should have a library that is adequately funded with the right infrastructure, collections, and information technology facilities such as functional library software. Library automation no doubt offered the libraries myriads of benefits that were not available before the 21 st century. Although, library software is very essential in effectively managing a library's collection especially in university libraries as seen from the study its use should be encouraged by all forms of users in the library.

\section{Recommendations}

Based on the findings from the study the following are the recommendations;

1. Undergraduates at all levels should be encouraged to use the library software by creating more awareness.

2. Undergraduates should be encouraged to make use of the software regularly when searching for library materials instead of moving from one shelve to another.

3. Bowen and. Redeemers university libraries should regularly evaluate accessibility and use of library software by undergraduates by taking the statistics of undergraduates that makes use of the software package regularly.

4. Bowen University should acquire more computers for accessing the library software and also seek for alternative power supply source.

5. Redeemer's university library should increase their bandwidth for internet connection in order to combat the problem of frequent down time of server. 


\section{References}

Abolaji, J.A., 2000. Automation of cataloguing processes in Nigerian libraries: The experience of Hezekiah Oluwasanmi library. Ile-Ife, Nigerian: Obafemi Awolowo University.

Belfied, J. and P. Lerin, 2003. In Ajadi, T. O. (2010), Private universities in Nigeria- the challenges ahead. American Journal of Scientific Research: 7 .

Bensode, S. and S. Periera, 2008. A survey of library automation in college libraries in Goa State India. Library Philosophy and Practice. Available from http:// www.webpages,videho.edu/.

Brosnan, M.J., 1998. The impact of computer anxiety and self-efficacy upon performance. Journal of Computer Assisted Learning, 14(3): 223235. View at Google Scholar | View at Publisher

Dyck, J.L. and J.A. Smither, 1994. Age differences in computer anxiety: The role of computer experience, gender and education. Journal of Educational Computing Research, 10(3): 239-248. View at Google Scholar | View at Publisher

Edem, M.B., 2016. Adoption of software packages in university libraries in Nigeria library philosophy and practice (E-Journal). Paper No. 1342 .

Ehikhamenor, F.A., 1993. Information technology and scientific and technological in Nigeria: Revolution or evolution? African Journal of Library, Archival, and Information Science, 3(2): 113-123. View at Google Scholar

Fatoki, O.C., 2002. Trends and standards in software selection in Nigerian libraries. Gateway Library Journal, 5(1 \& 2): 4-5. View at Google Scholar

Ford, N. and D. Miller, 1996. Gender difference in internet perception and use: In Collier, M. and Arnold, K. (Eds.), Electronic Library and Visual Information Research, ELVIRA 3: Papers from the Third" ELVIRA Conference 30 "'April 2 May 1996, 87 10 0 London AS LIB.

Ford, N., D. Miller and N. Moss, 2001. The role of individual difference in internet searching: An empirical study. Journal of the American Society for Information Science and Technology, 52(12): 1049-1066. View at Google Scholar | View at Publisher

Harinarayana, N.S. and K.S. Raghavan, 2008. Retrieval capabilities of CDS/ISIS and LibSys: A comparison. Annals of Library and Information Studies, 55(2): 91-100. View at Google Scholar

Ifidon, S.E., 1999. Essentials of African university library management. Nigeria: National Library Press Ltd.

Klatt, R., 2001. Barriers in using digital scientific information at German universities and other higher education institutions. Lecture at the 23rd DGI-Online Conference 2001, Frankfurt/M.

Koohang, A.A., 1986. Effects of age, gender, college status, and computer experience on attitudes toward library computer sys tems (LCS). Library and Information Science, Research, 8(4): 349-355. View at Google Scholar

Laerum, H., G. Ellingsen and A. Faxvaag, 2001. Doctors' use of electronic medical records systems in hospitals: Cross sectional survey. British Medical Journal, 323(7323): 1344-1348. View at Google Scholar | View at Publisher

Laguna, K. and R.L. Babcock, 1997. Computer anxiety in young and older adults: Implications for human-computer interactions in older populations. Computers in Human Behavior, 13(3): 317-326. View at Google Scholar | View at Publisher

lyoro, A.O., 2004. Serials availability, accessibility for use: Perception of in training information professionals in a Nigerian university. Nigerian Library Link, 11(2): 66-72.

Majid, S. and A.F. Abazova, 1999. Computer literacy and use of electronic information sources by academics: A case study of international islamic university Malaysia. Asian Libraries, 8(4): 100-111. View at Google Scholar View at Publisher

McGuigan, G.S., 2001. Databases versus the web: A discussion of teaching the use of electronic resources in the library instruction setting. Internet Reference Services Quarterly, 6(1): 39-47. View at Google Scholar | View at Publisher

Meer, V., P. Fravel, H. Poole and V.T. Van, 1997. Are library users also computer users? A survey of faculty and implications for services. Public-Access Computer Systems Review, 8(1). View at Google Scholar

Nnadozie, C.O. and C.D. Nnadozie, 2008. The information needs of faculty members in a Nigerian private university: A self-study. Library Philosophy and Practice. View at Google Scholar

Nok, G., 2006. The challenges of computerizing a university library in Nigeria: The case of Kashim Ibrahim library, Ahmadu Betlo University. Zaria: Library Philosophy and Practice.

Nwalo, K.I.N., 2003. Fundamentals of library practice a manual on library routines. Lagos: Stirling-Horden Publishers.

Okewale, O. and A. Adetimirin, 2011. Information use of software packages in Nigerian university libraries. Journal of Information Technology Impact, 1 1(3): 21 1-224. View at Google Scholar

Olaniyan, O., 2001. Public finance and higher education in Nigeria: Proceedings of the 12th General Assembly of the Social Science Academy of Nigeria (SSAN). pp: 101-119.

Olatokun, W.M., 2007. Availability, accessibility and use of ICTs by Nigerian women academics. Malaysian Journal of Library \& Information Science, 12(2): 13-33.

Osundina, O., 1974. The relationship between accessibility and uses made of the academic library by undergraduate students. Nigerian Libraries, 41. View at Google Scholar

Popoola, S.O., 2008. The use of information sources and services and its effect on the research output of social scientists in Nigerian Universities. Library Philosophy and Practice. Available from http://www.webpages.uidaho.edu/ mbolin/popoola.htm.

Ranganathan, S.R., 1931. The five laws of library science. London: Edward Goldston.

Sacks, C.H., Y. Bellissimo and J.R. Mergendoller, 1994. Attitudes toward computers and computer use: The issue of gender. Journal of Research on Computing in Education, 26(2): 256-269.

Sayan, S., S. Elci and H. Acvi, 2004. Factors and impact in information society: A prospective analysis in the candidate coun tries. Report on Turkey.

Seth, M.K. and B. Parida, 2006. Information needs and use pattern of disadvantaged communities: A case study. Library Philosophy and Practice, 9(1). View at Google Scholar

Singh, Y., 2003. Library automation in academic libraries in India: Problems and prospects. In Caliber. Available from http://dspace,inmbnetac.in/bitstream/1944/188/3/03cali_19.pdfSocketWorksNigeriaLimited.

Ugah, A., 2007. Evaluating the use of university libraries in Nigeria: A case study of Michael Okpara university of agriculture, Umudike. University libraries. Journal of Information Technology Impact, 1 1(3): 211 - 224. View at Google Scholar

Whitmire, E., 2001a. The relationship between undergraduates' background characteristics and college experiences and their academic library use. College and Research Libraries, 62(6): 528-540.

Whitmire, E., 2001b. A longitudinal study of undergraduates' academic library experiences. Journal of Academic Librarianship, 27(5): 379385 .

Whitmire, E., 2002. Academic library performance measures and undergraduates' library use and educational outcomes. Library \& Information Science Research, 24(2): 107-128. View at Google Scholar | View at Publisher

World Health Organization, 2011

Yuandong, Y., W. Zhan and T. Lai, 2005. How individual differences influence technology user's behavior? Toward an integrated framework. Available from hrJp://www.aIlbusinessxom/technology/computer-software-customer-reiation/1 054798-l.html.

Zaid, Y., 2004. Automating library records using glass software: The university of Lagos experience. Nigerian Libraries, 38(1): 56-57. View at Google Scholar 